\title{
Hepatoprotective Efficacy of Picrorhiza kurroa in Experimentally induced Hepatotoxicity in Cockerels
}

\author{
Praveen Kumar $^{1 *}$ and S.K. Shukla ${ }^{2}$ \\ ${ }^{1}$ Department of Veterinary Clinical Medicine, Ranchi Veterinary College, Kanke, Ranchi, \\ Jharkhand 834006, India \\ ${ }^{2}$ Department of Veterinary Medicine, Ethics and Jurisprudence, College of Veterinary and \\ Animal Sciences, G.B. Pant University of Agriculture and Technology, Pantnagar 263145 \\ U.S. Nagar, Uttarakhand, India \\ *Corresponding author
}

\begin{tabular}{|c|c|}
\hline & A B S T R A C T \\
\hline $\begin{array}{l}\text { Ke y w o r d s } \\
\text { Picrorhiza } \\
\text { kurroa, } \\
\text { Hepatoprotective } \\
\text { activity, } \\
\text { Biochemical } \\
\text { profile, } \\
\text { Cockerels. }\end{array}$ & \multirow{3}{*}{$\begin{array}{l}\text { Hepatoprotective properties of ethanolic and aqueous extracts of Picrorhiza } \\
\text { kurroa rhizomes were evaluated in cockerels given acetaminophen @ } 500 \mathrm{mg} / \\
\text { body weight orally to induce hepatocellular damage. Ethanolic extract given @ } 50 \\
\mathrm{mg} / \mathrm{kg} \text { body wt and acetaminophen helped in restoration of Hb, PCV, TEC, TLC } \\
\text { and lymphocytes and heterophils as well as total protein, albumin and globulin, } \\
\text { glucose, cholesterol, bilirubin and activity of AST, ALT, ALP and LDH. } \\
\text { Histopathological examination of liver section of treated birds clearly showed } \\
\text { normal hepatic cells and central vein thereby confirming hepatoprotective activity. } \\
\text { Silymarin used @ } 200 \mathrm{mg} / \mathrm{kg} \text { body weight as reference standard also showed the } \\
\text { same results. Aqueous extract revealed the least activity. Phytochemical analysis } \\
\text { of ethanolic extract showed presence of alkaloids, flavonoids, glycosides, } \\
\text { protein, resin, saponin, sterol and tannins. }\end{array}$} \\
\hline Article Info & \\
\hline $\begin{array}{l}\text { Accepted: } \\
\text { 25 March } 2017 \\
\text { Available Online: } \\
10 \text { April } 2017\end{array}$ & \\
\hline
\end{tabular}

\section{Introduction}

Many toxins damage the liver and affect its functions resulting in poor health and production. For prevention of hepatocytes, some drugs or chemicals are used which also antagonize the toxins and help to regain its power of metabolism, during early days, liver extract derived from liver of other mammals or fishes was the drug of choice. But such drugs posed serious risk of transmitting infections from animals to animals or to human. Moreover, the cost of liver extract is high specially if economy of the farm and farm products become a matter of concern. Now-a-day herbal liver formulations become more important in treating hepatic diseases. Picrorhiza kurroa has been used to treat disorders of the liver and upper respiratory tract, fevers, treat dyspepsia, chronic diarrhoea and scorpion sting (Sood and Chauhan, 2010). Picrorhiza has been shown to protect liver cells from a wide variety of toxins including amanita poisoning, carbon tetrachloride (Lee et al., 2007), galactosamine (Dwivedi et al., 1992), ethanol (Rastogi et al., 
1996), aflatoxin-B1 (Dwivedi et al., 1993), acetaminophen (Singh et al., 1992), and thioacetamide (Dwivedi et al., 1991), in both in vitro and in vivo experiments. The present study was planned to investigate the activity of $P$. kurroa on liver function markers following experimentally induced hepatotoxicity in cockerel.

\section{Materials and Methods}

The rhizomes of $P$. kurroa procured from local market, were identified and authenticated from Department of Biological Sciences of university. These were shade dried and ground in a Willey Grinder at room temperature. For preparation of the ethanolic or aqueous extract, $100 \mathrm{gm}$ each powder of $P$. kurroa was soaked in 1 liter of absolute ethanol or water for $48 \mathrm{hr}$ at $37^{\circ} \mathrm{C}$ with continuous stirring, the contents were filtered, concentrated at $45-50^{\circ} \mathrm{C}$ and reduced pressure using rotatory vacuum evaporator (Singh, 2001), lyophilized to get the final extract residue and stored at $4^{0} \mathrm{C}$ till further use.

The extracts were analysed for major phytochemical groups, viz. alkaloids, anthraquinones, flavonoids, saponins, tannins, sterols, reducing sugars, glycosides, resins, triterpenes, proteins and coumarins using methods at Das et al. (1964), Harborne (1973), Sofawara (1982) and Arunadevi (2003).

Total 100, three-month-old cockerels of same hatch were procured from IPF university and randomly divided into 5 groups I, II, III, IV and $\mathrm{V}$ of 20 each having almost equal average body weight and maintained under standard deep litter managemental conditions. Gr I served as healthy control, while gr II received acetaminophen @ $500 \mathrm{mg} / \mathrm{kg}$ body weight orally for 7 days (Bhar et al., 2009) and served as infected control. Gr III received silymarin (as a standard reference) along with acetaminophen for 7 days and thereafter only silymarin was given upto $35^{\text {th }}$ day. In gr IV and $\mathrm{V}$, ethanolic and aqueous extract residues @ $50 \mathrm{mg} / \mathrm{kg} \mathrm{b}$ wt (Jeyakumar et al., 2009) along with acetaminophen for 7 days and thereafter only extract were given upto $35^{\text {th }}$ day.

The blood samples were collected on day 0,7 , $15,21,28,35$ and 42 of treatment, for haematological $(\mathrm{Hb}, \mathrm{TEC}, \mathrm{TLC}, \mathrm{PCV}$ and DLC) and biochemical parameters (glucose, total cholesterol, total protein, albumin, globulin, albumin: globulin ratio, blood urea nitrogen and serum bilirubin and activities of enzymes AST, ALT, ALP and LDH) using standard methods.

Liver samples were collected in 10\% buffered formalin for histopathological examination on 7, 21 and 35 day of treatment. The results were analysed as per method described by Snedecor and Cochran (1994).

\section{Results and Discussion}

The ethanolic extract residue was greenish brown in color and oily in consistency while aqueous extract residue was light brown in color and solid dry powder in consistency. Ethanolic and aqueous extract revealed $16.09 \%$ and $13.23 \%$ yield. Phytochemical analysis of ethanolic extract of P. kurroa showed presence of alkaloids, flavonoids, glycosides, protein, resin, saponin, sterol and tannins, whereas alkaloids, proteins, resin and sterol were absent in aqueous extracts and anthraquinones and triterpenes were present

There was significant decrease in $\mathrm{Hb}, \mathrm{PCV}$, TEC and lymphocytic values in group II as compared to group I, III, IV and V from $7^{\text {th }}$ day onward up to the end of experiment (Table 1). Ethanolic and aqueous extract, significantly restored these values to 
normalcy. $\mathrm{Hb}$ values are significantly higher in treated group than untreated and control group at $42^{\text {nd }}$ day of treatment (Table 1). Destruction of RBC, decrease in TEC and $\mathrm{Hb}$ may be due to oxidative damage-mediated removal of affected erythrocyte, induced by acetaminophen. Increased generation of free radicals can cause cell membrane damage, which in turn inactivate membrane $\mathrm{Na}^{+}-\mathrm{K}^{+}$ATPase (Kumar et al., 2009), thereby allows entry of $\mathrm{Ca}^{+2}$ into the cell. The sustained increase in intracellular calcium leads to freeradical generation, which in turn $\mathrm{Na}^{+}-\mathrm{K}^{+}$. ATPase. Thus the acetaminophen mediated generation of free-radicals and consequent oxidative damage to erythrocytes can cause mechanical fragility of plasma membrane, thereby shortened RBC life span and its removal from circulation. Disintegration of erythrocytes in the circulation might have resulted in reduction of haemoglobin content of blood, which in turn was associated with decrease in PCV and TEC (Chauhan et al., 2008)

The ethanolic extract $P$. kurroa protected the disintegration of erythrocytes. Mogre et al. (1982) found that P. kurroa restored $\mathrm{Na}^{+}-\mathrm{K}^{+}-$ ATPase levels to normal in paracetamol and aflatoxin induced hepatic injury. Neutrophilia and lymphocytopenia in all the animals subjected to hepatopathy. This might be due to stress coupled with inflammatory changes in body tissue, which is responsible for phagocytosis of toxic substances and neutrophilia was induced by tissue demand for phagocytic function (Duncan and Prasse, 1977). Increase in heterophils and decrease in lymphocytes was also reported by Hadau et al. (2008). Rukamani et al. (1998) also found restoration of TLC with the administration of P. kurroa.

Glucose and bilirubin showed marked increase after induction of hepatopathy in untreated group from $7^{\text {th }}$ day till end of experiment (Table 2). There was significant decrease in of total protein, albumin and cholesterol levels and increase in globulin in all the treated groups (Table 2). Hyperglycaemia can be due to the degenerative hepatic lesions and also can follow the metabolic acidosis. Reduction in glucose level after the treatment with extracts was also reported by Talmale et al. (2010). Due to the damage of hepatocytes there was decreased elimination of bilirubin and thus an increase was observed. The increase in bilirubin was also observed by Vaidya et al. (1996) and Talmale et al. (2010). Kaneko (1989) and Mezey (1978) reported that protein synthesized by the liver are frequently decreased in patients with liver diseases and this was manifested clinically by decrease in circulating proteins such as albumin. These values came down to normalcy following therapy indicating the therapeutic values of the drug. Globulins are intermediate proteins which are involved in antibody formation. Jaykumar et al. (2008, 2009) and Talmale et al. (2010) also observed the same findings. Hepatic cholesterol homeostasis is maintained by equilibrium between the activities of hydroxy methyl glutaryl CoA (HMG-CoA) reductase and that of acyl CoA: cholesterol acyl transferase (Hochgraf et al., 2000). Reduction in cholesterol could also be due to the deficient metabolism of lipids in the liver (Gauda et al., 1985). Hussain (2009) also noticed decrease in cholesterol level with use of P. kurroa.

The activities of ALT, AST, ALP and LDH were elicited in infective group suggesting damage of liver hepatocytes and impairment of liver functions. Use of $P$. kurroa extracts and silymarin significantly reduced the level of these enzymes (Table 2). One of the hallmark signs of hepatic injury or damage is apparent leakage of cellular enzymes into plasma (Kumar et al., 2009). These enzymes are commonly used as marker enzymes in accessing hepatotoxicity (Yanpallewar et al., 2003; Asha et al., 2004 and Yen et al., 2007). 
Table.1 The value of Hb, PCV, TEC, TLC, Lymphocytes and Heteropphils in cockerels treated with Picrorhiza kurroa

\begin{tabular}{|c|c|c|c|c|}
\hline Haematological & O day & $7^{\text {th }}$ day & $28^{\text {th }}$ day & $42^{\text {nd }}$ day \\
\hline \multicolumn{5}{|l|}{ Haemoglobin } \\
\hline Group 1 & $89.7 \pm 0.892$ & $89.2 \pm 0.778^{\mathrm{a}}$ & $97.8 \pm 0.443^{\mathrm{a}}$ & $99.6 \pm 1.771^{\mathrm{a}}$ \\
\hline Group II & $87.5 \pm 0.638$ & $71.2 \pm 0.704^{b}$ & $73.6 \pm 1.185^{b}$ & $80.1 \pm 1.336^{b}$ \\
\hline Group III & $89.1 \pm 0.842$ & $87.1 \pm 0.678^{\mathrm{a}}$ & $101.7 \pm 1.731^{\mathrm{c}}$ & $109.7 \pm 0.622^{c}$ \\
\hline Group IV & $86.8 \pm 1.135$ & $87.9 \pm 1.571^{\mathrm{a}}$ & $100.2 \pm 1.743^{\mathrm{ac}}$ & $107.0 \pm 0.522^{c}$ \\
\hline Group V & $86.8 \pm 1.199$ & $84.7 \pm 0.505^{\mathrm{a}}$ & $96.6 \pm 1.649^{a}$ & $104.2 \pm 1.507^{\mathrm{c}}$ \\
\hline \multicolumn{5}{|l|}{ PCV } \\
\hline Group 1 & $22.5 \pm 0.957$ & $22.75 \pm 0.629^{\mathrm{a}}$ & $28.25 \pm 0.854^{\mathrm{a}}$ & $29.75 \pm 1.493^{\mathrm{a}}$ \\
\hline Group II & $22.25 \pm 0.479$ & $17 \pm 0.707^{\mathrm{b}}$ & $18.25 \pm 0.629^{b}$ & $19.25 \pm 0.479^{b}$ \\
\hline Group III & $23 \pm 0.707$ & $21.75 \pm 0.479^{a}$ & $32.5 \pm 0.289^{c}$ & $32.25 \pm 0.854^{\mathrm{a}}$ \\
\hline Group IV & $22.5 \pm 0.009$ & $21.5 \pm 0.006^{\mathrm{a}}$ & $31.2 \pm 0.016^{\mathrm{ac}}$ & $32.2 \pm 0.014^{\mathrm{a}}$ \\
\hline Group V & $22.2 \pm 0.011$ & $22 \pm 0.007^{\mathrm{a}}$ & $30.5 \pm 0.019^{\mathrm{ac}}$ & $32.2 \pm 0.008^{\mathrm{a}}$ \\
\hline \multicolumn{5}{|l|}{ TEC } \\
\hline Group 1 & $2.283 \pm 0.149$ & $2.400 \pm 0.103^{\mathrm{a}}$ & $2.682 \pm 0.016^{\mathrm{a}}$ & $2.646 \pm 0.018^{\mathrm{a}}$ \\
\hline Group II & $2.238 \pm 0.115$ & $1.771 \pm 0.096^{b}$ & $2.292 \pm 0.051^{b}$ & $2.403 \pm 0.102^{b}$ \\
\hline Group III & $2.414 \pm 0.048$ & $2.368 \pm 0.123^{\mathrm{a}}$ & $2.659 \pm 0.014^{\mathrm{a}}$ & $2.727 \pm 0.031^{\mathrm{a}}$ \\
\hline Group IV & $2.400 \pm 0.080$ & $2.281 \pm 0.070^{\mathrm{a}}$ & $2.668 \pm 0.024^{\mathrm{a}}$ & $2.702 \pm 0.034^{\mathrm{a}}$ \\
\hline Group V & $2.306 \pm 0.049$ & $2.184 \pm 0.096^{\mathrm{a}}$ & $2.694 \pm 0.027^{\mathrm{a}}$ & $2.668 \pm 0.024^{\mathrm{a}}$ \\
\hline \multicolumn{5}{|l|}{ TLC } \\
\hline Group 1 & $17.150 \pm 0.552$ & $19.069 \pm 0.387^{\mathrm{a}}$ & $18.267 \pm 0.238^{\mathrm{a}}$ & $18.223 \pm 0.379^{\mathrm{a}}$ \\
\hline Group II & $17.405 \pm 0.185$ & $24.849 \pm 0.913^{b}$ & $22.854 \pm 0.913^{b}$ & $23.254 \pm 0.465^{b}$ \\
\hline Group III & $17.853 \pm 0.592$ & $18.377 \pm 0.648^{\mathrm{a}}$ & $18.305 \pm 0.606^{\mathrm{a}}$ & $18.589 \pm 0.360^{\mathrm{a}}$ \\
\hline Group IV & $17.989 \pm 0.427$ & $18.422 \pm 0.465^{\mathrm{a}}$ & $18.066 \pm 0.745^{\mathrm{a}}$ & $18.456 \pm 0.625^{\mathrm{a}}$ \\
\hline Group V & $17.715 \pm 0.654$ & $17.397 \pm 0.685^{\mathrm{a}}$ & $19.529 \pm 0.450^{\mathrm{a}}$ & $17.326 \pm 0.447^{\mathrm{a}}$ \\
\hline \multicolumn{5}{|l|}{ Lymphocytes } \\
\hline Group 1 & $10.898 \pm 0.723$ & $10.744 \pm 0.393^{\mathrm{a}}$ & $11.026 \pm 0.385^{\mathrm{a}}$ & $11.183 \pm 0.530^{\mathrm{a}}$ \\
\hline Group II & $10.168 \pm 0.449$ & $8.901 \pm 0.527^{b}$ & $9.012 \pm 0.427^{b}$ & $9.619 \pm 0.286^{b}$ \\
\hline Group III & $10.036 \pm 0.447$ & $10.956 \pm 0.531^{\mathrm{a}}$ & $11.038 \pm 0.683^{\mathrm{a}}$ & $11.883 \pm 0.471^{\mathrm{a}}$ \\
\hline Group IV & $10.528 \pm 0.796$ & $10.988 \pm 0.352^{\mathrm{a}}$ & $11.741 \pm 0.440^{\mathrm{a}}$ & $10.978 \pm 0.154^{\mathrm{a}}$ \\
\hline Group V & $10.632+0.805$ & $10.067 \pm 0.362^{\mathrm{a}}$ & $10.977 \pm 0.353^{\mathrm{a}}$ & $11.792+0.182^{a}$ \\
\hline \multicolumn{5}{|l|}{ Heterophils } \\
\hline Group 1 & $4.943 \pm 0.459$ & $4.916 \pm 0.567^{\mathrm{a}}$ & $5.060 \pm 0.226^{\mathrm{a}}$ & $5.438 \pm 0.166^{\mathrm{a}}$ \\
\hline Group II & $4.701 \pm 0.514$ & $7.630 \pm 0.599^{b}$ & $6.676 \pm 0.250^{b}$ & $6.100 \pm 0.159^{b}$ \\
\hline Group III & $4.577 \pm 0.238$ & $5.087 \pm 0.676^{\mathrm{a}}$ & $4.911 \pm 0.415^{\mathrm{a}}$ & $5.398 \pm 0.166^{\mathrm{a}}$ \\
\hline Group IV & $4.796 \pm 0.242$ & $5.020 \pm 0.708^{\mathrm{a}}$ & $4.948 \pm 0.171^{\mathrm{a}}$ & $5.305 \pm 0.096^{\mathrm{a}}$ \\
\hline Group V & $4.877 \pm 0.207$ & $5.283 \pm 0.730^{\mathrm{a}}$ & $5.133 \pm 0.300^{\mathrm{a}}$ & $5.356 \pm 0.094^{\mathrm{a}}$ \\
\hline
\end{tabular}


Table.2 The value of Glucose, Cholestrol, Total Protein, Albumin, Globulin and A: G ratio in cockerels treated with Picrorhiza kurroa

\begin{tabular}{|c|c|c|c|c|}
\hline Biochemical & 0 day & $7^{\text {th }}$ day & $28^{\text {th }}$ day & $42^{\text {nd }}$ day \\
\hline \multicolumn{5}{|l|}{ Glucose } \\
\hline Group 1 & $10.633 \pm 0.225$ & $9.302 \pm 0.202^{\mathrm{a}}$ & $9.846 \pm 0.214^{\mathrm{a}}$ & $9.705 \pm 0.331^{\mathrm{a}}$ \\
\hline Group II & $9.737 \pm 0.216$ & $20.290 \pm 1.746^{b}$ & $17.085 \pm 1.419^{b}$ & $13.717 \pm 1.037^{\mathrm{b}}$ \\
\hline Group III & $10.635 \pm 0.583$ & $11.144 \pm 1.105^{\mathrm{a}}$ & $10.014 \pm 0.236^{\mathrm{a}}$ & $9.699 \pm 0.305^{\mathrm{a}}$ \\
\hline Group IV & $9.583 \pm 0.295$ & $12.100 \pm 1.164^{\mathrm{a}}$ & $9.823 \pm 0.227^{\mathrm{a}}$ & $9.580 \pm 0.324^{\mathrm{a}}$ \\
\hline Group V & $10.060 \pm 0.529$ & $11.247 \pm 0.319^{\mathrm{a}}$ & $9.926 \pm 0.898^{a}$ & $10.226 \pm 0.140^{\mathrm{a}}$ \\
\hline \multicolumn{5}{|l|}{ Cholestrol } \\
\hline Group 1 & $4.326 \pm 0.137$ & $4.368 \pm 0.038$ & $4.287 \pm 0.106^{\mathrm{a}}$ & $4.372 \pm 0.037^{\mathrm{a}}$ \\
\hline Group II & $4.336 \pm 0.062$ & $4.579 \pm 0.097$ & $5.261 \pm 0.113^{b}$ & $4.937 \pm 0.252^{b}$ \\
\hline Group III & $4.342 \pm 0.055$ & $4.480 \pm 0.059$ & $4.282 \pm 0.064^{\mathrm{a}}$ & $4.415 \pm 0.055^{\mathrm{a}}$ \\
\hline Group IV & $4.379 \pm 0.123$ & $4.352 \pm 0.116$ & $4.388 \pm 0.025^{\mathrm{a}}$ & $4.362 \pm 0.095^{\mathrm{a}}$ \\
\hline Group V & $4.374 \pm 0.021$ & $4.326 \pm 0.109$ & $4.361 \pm 0.095^{\mathrm{a}}$ & $4.277 \pm 0.114^{\mathrm{a}}$ \\
\hline \multicolumn{5}{|l|}{ Total protein } \\
\hline Group 1 & $58.665 \pm 2.666$ & $62.843 \pm 2.188^{\mathrm{ac}}$ & $61.918 \pm 2.453^{\mathrm{a}}$ & $62.408 \pm 1.371^{\mathrm{a}}$ \\
\hline Group II & $58.615 \pm 2.147$ & $45.878 \pm 1.575^{b}$ & $47.993 \pm 1.842^{b}$ & $50.783 \pm 2.053^{b}$ \\
\hline Group III & $59.243 \pm 2.579$ & $63.438 \pm 2.500^{\mathrm{a}}$ & $68.870 \pm 1.193^{\mathrm{c}}$ & $67.513 \pm 2.794^{\mathrm{a}}$ \\
\hline Group IV & $60.548 \pm 3.18$ & $61.96 \pm 01.56^{\mathrm{a}}$ & $68.543 \pm 3.46^{\mathrm{c}}$ & $67.990 \pm 3.16^{\mathrm{a}}$ \\
\hline Group V & $63.430 \pm 0.23$ & $58.438 \pm 1.16^{\mathrm{a}}$ & $67.223 \pm 1.67^{\mathrm{ac}}$ & $63.013 \pm 1.14^{\mathrm{a}}$ \\
\hline \multicolumn{5}{|l|}{ Albumin } \\
\hline Group 1 & $34.553 \pm 2.305$ & $35.955 \pm 1.482^{\mathrm{a}}$ & $35.425 \pm 1.697^{\mathrm{a}}$ & $35.470 \pm 0.921$ \\
\hline Group II & $33.473 \pm 1.057$ & $27.510 \pm 1.472^{b}$ & $27.600 \pm 1.177^{\mathrm{b}}$ & $30.268 \pm 1.919$ \\
\hline Group III & $35.173 \pm 1.531$ & $34.323 \pm 2.420^{\mathrm{a}}$ & $35.620 \pm 1.264^{\mathrm{a}}$ & $36.058 \pm 1.397$ \\
\hline Group IV & $35.395 \pm 2.191$ & $34.203 \pm 1.993^{\mathrm{a}}$ & $35.053 \pm 2.405^{\mathrm{a}}$ & $35.480 \pm 0.926$ \\
\hline Group V & $35.968 \pm 1.275$ & $32.408 \pm 0.902^{\mathrm{a}}$ & $34.818 \pm 1.239^{\mathrm{a}}$ & $31.995 \pm 1.192$ \\
\hline \multicolumn{5}{|l|}{ Globulin } \\
\hline Group 1 & $24.113 \pm 0.825$ & $26.888 \pm 1.046^{\mathrm{a}}$ & $26.493 \pm 1.229^{\mathrm{a}}$ & $26.938 \pm 1.590^{\mathrm{a}}$ \\
\hline Group II & $25.143 \pm 1.394$ & $18.368 \pm 0.747^{b}$ & $20.393 \pm 1.170^{b}$ & $20.515 \pm 0.719^{b}$ \\
\hline Group III & $24.070 \pm 1.204$ & $29.115 \pm 2.049^{\mathrm{a}}$ & $33.250 \pm 1.456^{\mathrm{c}}$ & $31.455 \pm 1.866^{\mathrm{c}}$ \\
\hline Group IV & $25.153 \pm 1.944$ & $27.758 \pm 1.260^{\mathrm{a}}$ & $33.490 \pm 1.855^{\mathrm{C}}$ & $32.510 \pm 2.345^{c}$ \\
\hline Group V & $27.463 \pm 1.183$ & $26.030 \pm 0.972^{a}$ & $32.405 \pm 1.656^{\mathrm{c}}$ & $31.018 \pm 0.964^{\mathrm{ac}}$ \\
\hline \multicolumn{5}{|l|}{ A:G ratio } \\
\hline Group 1 & $1.435 \pm 0.095$ & $1.340 \pm 0.055$ & $1.342 \pm 0.070^{\mathrm{ab}}$ & $1.334 \pm 0.100^{\mathrm{ab}}$ \\
\hline Group II & $1.340 \pm 0.059$ & $1.506 \pm 0.099$ & $1.463 \pm .083^{\mathrm{b}}$ & $1.481 \pm 0.106^{\mathrm{b}}$ \\
\hline Group III & $1.464 \pm 0.045$ & $1.200 \pm 0.125$ & $1.080 \pm 0.072^{\mathrm{c}}$ & $1.144 \pm .059^{\mathrm{c}}$ \\
\hline Group IV & $1.428 \pm 0.126$ & $1.247 \pm 0.126$ & $1.053 \pm 0.074^{\mathrm{c}}$ & $1.103 \pm 0.056^{\mathrm{c}}$ \\
\hline Group V & $1.324 \pm 0.111$ & $1.251 \pm 0.064$ & $1.085 \pm 0.077^{\mathrm{c}}$ & $1.036 \pm 0.061^{\mathrm{c}}$ \\
\hline
\end{tabular}


Table.3 The activities of AST, ALT, ALP and LDH in cockerels treated with Picrorhiza kurroa

\begin{tabular}{|c|c|c|c|c|}
\hline Biochemical & 0 day & $\mathbf{7}^{\text {th }}$ day & $\mathbf{2 8}^{\text {th }}$ day & $\mathbf{4 2}^{\text {nd }}$ day \\
\hline AST & & & & \\
\hline Group 1 & $391 \pm 15.138$ & $402 \pm 19.399^{\mathrm{a}}$ & $404 \pm 11.453$ & $401 \pm 7.692$ \\
\hline Group II & $385 \pm 16.350$ & $621 \pm 12.754^{\mathrm{b}}$ & $463 \pm 16.361$ & $441 \pm 22.587$ \\
\hline Group III & $397 \pm 17.093$ & $411 \pm 16.366^{\mathrm{a}}$ & $404 \pm 8.554$ & $419 \pm 14.646$ \\
\hline Group IV & $402 \pm 13.279$ & $415 \pm 20.046^{\mathrm{a}}$ & $408 \pm 11.540$ & $401 \pm 17.093$ \\
\hline Group V & $397 \pm 7.223$ & $417 \pm 9.721^{\mathrm{a}}$ & $403 \pm 6.178$ & $411 \pm 10.008$ \\
\hline ALT & & & & \\
\hline Group 1 & $98 \pm 3.697$ & $100 \pm 4.882^{\mathrm{a}}$ & $101 \pm 1.080^{\mathrm{a}}$ & $110 \pm 2.828$ \\
\hline Group II & $99 \pm 1.472$ & $309 \pm 8.256^{\mathrm{b}}$ & $128 \pm 9.704^{\mathrm{b}}$ & $122 \pm 7.494$ \\
\hline Group III & $100 \pm 1.683$ & $113 \pm 4.601^{\mathrm{a}}$ & $101 \pm 2.582^{\mathrm{a}}$ & $113 \pm 3.488$ \\
\hline Group IV & $99 \pm 3.488$ & $112 \pm 0.816^{\mathrm{a}}$ & $100 \pm 3.979^{\mathrm{a}}$ & $111 \pm 1.080$ \\
\hline Group V & $101 \pm 2.483$ & $118 \pm 5.447^{\mathrm{a}}$ & $111 \pm 4.378^{\mathrm{a}}$ & $113 \pm 2.345$ \\
\hline ALP & & & & \\
\hline Group 1 & $123 \pm 5.196$ & $126 \pm 8.287^{\mathrm{a}}$ & $124 \pm 4.378$ & $122 \pm 2.799$ \\
\hline Group II & $121 \pm 7.106$ & $343 \pm 4.708^{\mathrm{c}}$ & $148 \pm 5.115$ & $141 \pm 3.391$ \\
\hline Group III & $124 \pm 4.378$ & $135 \pm 8.175^{\mathrm{a}}$ & $130 \pm 5.066$ & $125 \pm 4.491$ \\
\hline Group IV & $125 \pm 5.323$ & $134 \pm 7.594^{\mathrm{a}}$ & $132 \pm 4.813$ & $120 \pm 3.391$ \\
\hline Group V & $121 \pm 3.582$ & $140 \pm 3.109^{\mathrm{a}}$ & $128 \pm 5.066$ & $132 \pm 5.148$ \\
\hline LDH & & & & \\
\hline Group 1 & $479 \pm 16.010$ & $482 \pm 14.872^{\mathrm{a}}$ & $494 \pm 1.080$ & $486 \pm 9.018$ \\
\hline Group II & $484 \pm 19.506$ & $773 \pm 12.891^{\mathrm{b}}$ & $509 \pm 12.457$ & $493 \pm 3.082$ \\
\hline Group III & $482 \pm 11.225$ & $502 \pm 8.784^{\mathrm{a}}$ & $483 \pm 3.559$ & $486 \pm 4.848$ \\
\hline Group IV & $481 \pm 10.591$ & $504 \pm 5.354^{\mathrm{a}}$ & $491 \pm 4.528$ & $488 \pm 2.677$ \\
\hline Group V & $498 \pm 23.611$ & $522 \pm 17.762^{\mathrm{c}}$ & $496 \pm 7.106$ & $499 \pm 6.916$ \\
\hline
\end{tabular}

Recovery towards normalization of the enzymes following $P$. kurroa treatment suggested that the plant extract have role in preserving structural integrity of hepatocellular membrane, thus prevented enzymes leakage into circulation (Bhar et al., 2005, Singh et al., 2005 and Talmale et al., 2010).

There was significant decrease in feed consumption and body weight in group II as compared to group I, III, IV and V from $14^{\text {th }}$ day onward till end of experiment. A significant increase in body weight was observed in the group IV at $35^{\text {th }}$ day of treatment as compared to control group which might be due to increase in function of hepatocyte and increased palatability of feed.
The biochemical findings were supported with histopathological observations of liver sections. The healthy control group (Fig. 1) showed normal cellular architecture with sinusoidal spaces and central veins while intoxicated cockerels revealing centrilobular hepatic necrosis. The hepatic cords were irregularly distributed and distorted and the cells were rounded with opaque cytoplasm and showed mild vacuolated cells that suggested the fatty degeneration (Fig 2). In treated birds, hepitocellular changes could be restored towards normalcy.

These results indicated that Picrorhiza kurroa has hepatoprotective action. It increases the $\mathrm{Hb}$, PCV, TEC, lymphoctes, total protein, albumin and globulin levels and decreases 
glucose, total cholesterol, bilirubin, AST, ALT, ALP and LDH values to normalcy in intoxicated bird.

\section{Acknowledgments}

The authors are thankful to Dean, College of Post Graduate Science, Dean, College of Veterinary and Animal Sciences and Director Experiment Station, G.B. Pant University of Agriculture and Technology for providing necessary facilities to carry out this research work.

\section{References}

Arunadevi, R., 2003. Investigation on antiinflammatory, antinoceptive and antipyretic activities of different fractions of Caesalpimia bonducella. M.V.Sc. Thesis. I.V.R.I. Izatnagar, Bareilly, U.P., India

Asha, V. V., Akhila, S., Wills, P. I. and Subramoniam, A. 2004. Further studies on the antihepatotoxic activity of Phyllanthus maderaspatensis Linn. J Ethnopharmacology. 92: 67-70.

Atal, C. K., Sharma, M. L. , Kaul, A. , and Khajuria, A. 1986. Immunomodulating agents of plant origin. I: Preliminary screening. $J$ Ethnopharmacology.; 18:133-41.

Baruah C. C., Gupta, P. P., Nath, A., Patnaik, L. G. and Dhawan, B. N. 1998. Antiallergic and anti-anaphylactic activity of picroliv-a standardised iridoid glycoside fraction of Picrorhiza kurroa. Pharmacol Res.; 38:487-92.

Bhar, M. K., Das, S. K., Chakraborty, A. K., Mandal, T. K. and Roy, S. 2005. Hepatoprotective effect of Enliv® on paracetamol-induced liver damage in broiler chicks. Indian Journal of Pharmacology. 37: 257-58.

Bhar, M. K., Khargharia, S., Chakraborty, A. K. and Mandal, T. K. 2009. Disposition kinetics of sparfloxacin in healthy, hepatopathic, and nephropathic conditions in chicken after single intravenous administration. Indian Journal of Pharmacology. 41: 106-9

Chauhan S., Nath, N. and Tule, V. 2008. Antidiabetic and antioxidant effects of Picrorhiza kurroa rhizome extracts in diabetic rats. Indian Journal of Clinical Biochemistry. 23: $238-42$.

Chung, Y. H., Kim, J. A., Song Song, B. C., Koh, I. H., Lee, M. S., Eunsil, H. C., Lee, Y. S. and Su, D. I. 2001. Centrilobular hepatic necrosis; Isocitrate dehydrogenase as a marker of centrilobular model of rats. J Gastroen Hepatol. 16: 328-32.

Das, P. K., Nath, V., Gopde, K. D. and Sangal, A. K. 1964. Preliminary phytochemical and pharmacological studies on Coculus hirsutus Linn. Indian J Med Res. 52: 300.

Dorsch, W., Stuppner, H., Wagner, H., Gropp, M., Demoulin, S. and Ring, J. 1991. Antiasthmatic effects of Picrorhiza kurroa: androsin prevents allergen- and PAF-induced bronchial obstruction in guinea pigs. International Arch Allergy Applied Immunology.; 95:128-33.

Duncan, R. J. and Prasse, K. W. 1977. Veterinary Laboratory Medicine and Clinical Pathology, The Iowa State University Ames, Iowa.

Dwivedi, Y., Rastogi, R., Garg, N. K. and Dhawan B. N. 1992. Picroliv and its components kutkoside and picroside I protect liver against galactosamineinduced damage in rats. Pharmacol Toxicol. 71:383-87.

Dwivedi, Y., Rastogi, R., Mehrotra, R., Garg, N. K. and Dhawan, B. N. 1993. Picroliv protects against aflatoxin B1 acutehepatotoxicity in rats. Pharmacol Res.; 27:189-99.

Dwivedi, Y., Rastogi, R., Sharma, S. K., 
Garg, N. K. and Dhawan, B. N.1991. Picroliv affords protection against thioacetamideinduced hepatic damage in rats. Planta Med. 57:25-28.

Gauda, I. M., Aziz, S. A. A., Ahmed, A. A., Lofti, M. M. and Soliman, M. M.1985. Changes in liver function in experimentally lead poisoned goats. Arch. Fur. Experimental Veterinary Medicine. 39: 257-67.

Harborne J. B., 1973. Phytochemical methods. London. Chapman and Hall, Ltd. pp. 49-188.

Hedau M., Bhandarkar A. G., Raut, S. S. and Ingle, K. S., 2008. Haematobiochemical changes in experimental paracetamol toxicity in poultry. Indian J Poul Sci. 43: 2 .

Hochgraf, E., Cogan, U. and Shoshama, M. 2000. Dietary oxidized linoleic acid enhances liver cholesterol biosynthesis and secretion in rats. $J$ Nutr Biochem. 11: $176-80$

Husain, G. M., Singh, P. N. and Kumar, V., 2009. Antidiabetic activity of standardized extract of Picrorhiza kurroa in rat model of NIDDM. Drug Discoveries and Therapeutics. 3: 8892.

Jeyakumar, R., Rajesh, R., Meena, B., Rajaprabhu, D., Ganesan, B., Buddhan, S. and Anandan, R. 2008. Antihepatotoxic effect of Picrorhiza kurroa on mitochondrial defense system in antitubercular drugs (isoniazid and rifampicin)-induced hepatitis in rats. Journal of Medicinal Plants Research. 2: 17-19.

Jeyakumar, R., Rajesh, R., Rajaprabhu, D., Ganesan, B., Buddhan, S. and Anandan, R. 2009. Hepatoprotective effect of Picrorhiza kurroa on antioxidant defense system in antitubercular drugs induced hepatotoxicity in rats. African Journal of Biotechnology. 8: 1314-15.

Kaneko J. J., 1989. Clinical biochemistry of domestic animals. $4^{\text {th }}$ Edition. Academic Press, Inc. N.York..

Kumar, P., Prasad, R., Singh, K. K. and Roy, B. K. 2009. Hepatoprotective effect of Centella asiatica against paracetamol induced liver damage in broiler chicken. Indian J Poul Sci. 4: 101-04

Lee, H. S., Keum, K. Y. and Ku, S. K. 2007. Effects of Picrorrhiza rhizoma water extracts on the subacute liver damages induced by carbon tetrachloride. $\mathrm{J} \mathrm{Med}$ Food. 10: 110-17.

Mezey, E., 1978. Liver disease and nutrition. Gastroenterology. 74: 770-83.

Mogre, K., Vora, K. K. and Sheth, U. K. 1982. Effect of Picrorhiza kurroa and Eclipta alba on $\mathrm{Na}+\mathrm{K}+$ Atpase in hepatic injury by hepatotoxic agents. Indian J Pharma. 13: 253-59.

Rastogi, R., Saksena, S., Garg, N. K., Kapoor, N. K., Agarwal, D. P., Dhawan, B. N. 1996. Picroliv protects against alcoholinduced chronic hepatotoxicity in rats. Planta Med. 62:283-85.

Ruckmani, K., Kavimani, S., Anandan, R. and Jaykar, B. 1998. Effect of Moringa oleifera Lam. on paracetamol-induced hepatotoxicity. Indian J Pharmaceutical Sci. 60: 33-35.

Shyamal, S., Latha, P. G., Shine, V. J., Suja, S. R., Rajasekharan, S. and Devi, T. G. 2006. Hepatoprotective effects of Pittosporum neelgherrense Wight\&Arn., a popular Indian ethnomedicine. J. Ethnopharmacology. 107: 151-55.

Singh, V., Visen, P. K., Patnaik, G. K., Kapoor, N. K. and Dhawan, B. N.1992. Effect of picroliv on low density lipoproteinreceptor binding of rat hepatocytes in hepatic damage induced by paracetamol. Indian J Biochem Bio. 29:428-32.

Singh, B., 2001. Adaptogenic activity of a novel, with a nolide-free aqueous fraction from the roots of Withania 
somnifera Dun. Phytother Res. 15: 311-18.

Singh, M., Tiwari, V., Jain, A. and Ghoshal, S. 2005. Protective activity of picroliv on hepatic amoebiasis associated with carbon tetrachloride toxicity. Indian $J$ Med Res. 121: 676-82.

Snedecor, G. W. and Cochran, W. G. 1994. Statistical methods, $6^{\text {th }}$ Edn., Allied Pacific Pvt. Ltd., Bombay.

Sofaware, A., 1982. Medicinal plants and traditional medicine in Africa. Chichester, John Wiley.

Sood, H. and Chauhan, R. S. 2010. Biosynthesis and accumulation of a medicinal compound, Picroside-I, in cultures of Picrorhiza kurroa Royle ex Benth. Plant Cell Tiss Org. 100: 113-17 Talmale, V. R., More, P. R., Ghumare, B. C., Shendre, S. B. and Nirgulkar, S. N. 2010. Efficacy of Picrorhiza kurroa
Benth in experimentally induced hepatotoxicity in cross-bred calves. Veterinary World. 3: 29-31.

Vaidya, A. B., Antarkar, D. S. and Doshi, J. C. 1996. Picrorhiza kurroa (kutaki) as a hepatoprotective agent- experimental and clinical studies. J. Postgraduate Med. 42: 105-8.

Yanpallewar, S. U., Sen, S. , Tapas, S., Kumar, M., Raju, S. S. and Acharya, S. B. 2003. Effect of Azadirachta indica on paracetamol-induced hepatic damage in albino rats. Phytomedicine. 10: 39196.

Yen, F. L., Wu, T. H., Lin, L. T. and Lin, C. C. 2007. Hepatoprotective and antioxidant effect of Cuscata chinensis against acetaminophen-induced hepatotoxicity in rats. $J$. Ethnopharmacology. 111: 123-28.

\section{How to cite this article:}

Praveen Kumar and Shukla, S.K. 2017. Hepatoprotective Efficacy of Picrorhiza kurroa in Experimentally induced Hepatotoxicity in Cockerels. Int.J.Curr.Microbiol.App.Sci. 6(4): 26142622. doi: https://doi.org/10.20546/ijcmas.2017.604.304 